\title{
Beberapa Aspek Industri Pertekstilan Indonesia dan Dunia
}

Oleh : Chamroel Djafri

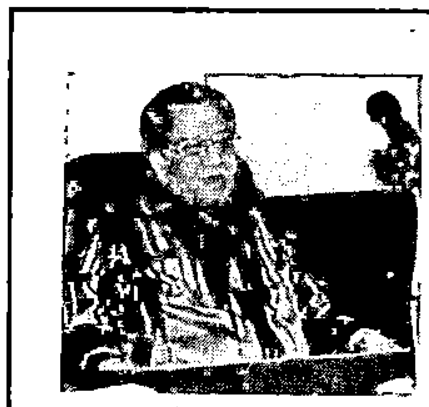

Chamroel DJafrl, lahir 5 Juni 1931 di Jakarta. Lulus sebagai Sarjana pada Fakultas Teknik Jurusan Teknik Sipil UGM tahun 1959. Sejak tahun 1987 menjabat sebagai Wakil Ketua Umum Asosiasi Perekstilan Indo nesia dan pernah bekerja di Departemen Perindustrian RI. Saat inijuga DirekturPT. Mayertex Indonesia. Tahun 1982 s/d 1987 menjadi Atase perindustrian di.KBRI Washington DC, danjuga pernah sebagai Direktur Utama PT. LEPPIN Tahun (1952 - 1982). Pada tahun 1977 s/d 1982 menjadi Direktur Utama PT. Industri Sandang II (persero)

Yang dimaksud dengan tekstil dalam perdagangan tekstil, ialah beñang dan lembaran tekstil, yaitu hasil dari industri filament dan pemintalan (spinning), pertemuan dan perajutan (weaving dan knitting), tekstil kempaan (non woven), pemutihan dan pencelupan (bleaching dan dyeing), sablon dan pencetakan (stenciling and printing).

Produk tekstil terdiri dari pakaian jadi (garment) dan produk lain (made up textile goods). Garment beserta perlengkapan lain, seperti tas, sepatu, perhiasan, ikat pinggang dsb-nya disebut apparel dan ditempat penjualan pada disatukan pada ruangan tersendiri, terpisah dari produk tekstil lainnya. Adakalanya tekstil rumah tangga disatu kelompokkan dengan pakaian jadi, sedangkan tekstil keperluan industri dan engineering kadangkadang dimasukkan kelompok tekstil.

Dalam tahun 1991 Indonesia sudah merupakan pemakai serat dan produsen benang pintal ke-9 dunia (lihat Tabel 1), tetapi dălam jumlah mata pintal berada padaurutanke-8(haraplihat tabel2). Masih banyaknya mata pintal yang mendekati obselete, yang perlu. dimodifikasi, rehabilitasi atau di-scrap menyebabkan perbedaan urutan diatas. Namun demikian, sebagian besarpabrik pemintalan yang baru sudah mempergunakan sistem staple spinning yang terakhir.

Pengembangan open-end. spinning di Indonesia tidak diutamakan, mengingat kemampuan pembuatan benang mesin ini, terbatas pada benang kasar, dan juga karena padat modal maka daya saingnya terhadap produk yang sama dari negara industri tidak terlalu jauh dibandingkan-dengan pemintalan biasa. Untuk menghindari konfrontasi langsung dengan negara maju maka policy ini harus dipertahankan, sambil menunggu waktu yang tepat.

Penambahan mata pintal dunia selama 4 tahun (1987-1991) adalah $\pm 12 \%$ 
menjadi $\pm 201 \%$ juta naik dengan $11,9 \%$. Selama waktu itu negara maju turun jumlah mata pintalnya,Amerika Utara turun dengan $(11,1 \%)$ menjadi $\pm 17,1$ juta, seluruh daratan
Eropa turun dengan $(12,5 \%)$ menjadi \pm 46,2 juta dan Japan turun dengan ' $(18,2 \%)$ menjadi 8 juta. Secara bersama, Korea, Taiwan, Hongkong dan Macao tetap pada

\begin{tabular}{|c|c|c|c|c|c|}
\hline \multicolumn{6}{|c|}{$\begin{array}{c}\text { Tabel 1 } \\
\text { Produksi Benang Dunia } 1991 \\
\text { Dalam ribu metric ton }\end{array}$} \\
\hline DAERAH/NEGARA & $\begin{array}{c}\text { KONSUMSI } \\
\text { KAPAS }\end{array}$ & $\begin{array}{l}\text { IMPOR } \\
\text { KAPAS }\end{array}$ & $\begin{array}{l}\text { BENANG } \\
\text { RAPAS }\end{array}$ & $\begin{array}{l}\text { BENANG } \\
\text { SERAT ** } \\
\text { BUATAN }\end{array}$ & $\begin{array}{l}\text { TOTAL } \\
\text { BENANG }\end{array}$ \\
\hline $\begin{array}{l}\text { DUNIA } \\
\text { AFRICA } \\
\text { NORTH AMERICA } \\
\text { SOUTH AMERICA } \\
\text { ASIA-OCEANIA } \\
\text { EUROPE } \\
\text { EUROPE-EEC } \\
\text { EUROPE-EFTA } \\
\text { EUROPE-EAST }\end{array}$ & $\begin{array}{r}18,449 \\
778 \\
2,226 \\
1,174 \\
10,917 \\
2,854 \\
1,204 \\
102 \\
2,048\end{array}$ & $\begin{array}{r}6,350 \\
223 \\
120 \\
283 \\
3,113 \\
2,508 \\
997 \\
103 \\
1,498\end{array}$ & $\begin{array}{r}16,714 \\
1 \\
515 \\
1,727 \\
878 \\
10,295 \\
2,961 \\
922 \\
72 \\
1,967\end{array}$ & $\begin{array}{r}17,500 \\
-167 \\
3,707 \\
483 \\
8,612 \\
4,531 \\
2,216 \\
286 \\
2,029\end{array}$ & $\begin{array}{r}34,214 \\
682 \\
5,434 \\
1,361 \\
18,907 \\
7,492 \\
3,138 \\
358 \\
3,996\end{array}$ \\
\hline $\begin{array}{l}\text { China } \\
\text { USA } \\
\text { USSR } \\
\text { Taiwan } \\
\text { India } \\
\text { Japan } \\
\text { KoRSEL } \\
\text { Pakistan } \\
\text { Indonesia } \\
\text { Germany } \\
\text { Brazil } \\
\text { Italy } \\
\text { Turkey } \\
\text { Mexico } \\
\text { Thailand } \\
\text { Spain } \\
\text { EgYpt } \\
\text { Rumania } \\
\text { France } \\
\text { Iran } \\
\text { Portugal } \\
\text { Hongkong } \\
\text { Poland } \\
\text { Czecoslovakia } \\
\text { Argentina } \\
\text { Columbia } \\
\text { Greece } \\
\text { Philippines } \\
\text { Bangladesh } \\
\text { Malaysia } \\
\text { Vietnam }\end{array}$ & $\begin{array}{r}4,107 \\
1,972 \\
1,705 \\
1365 \\
1,925 \\
626 \\
425 \\
1.400 \\
371 \\
198 \\
700 \\
325 \\
567 \\
174 \\
353 \\
144 \\
330 \\
66 \\
106 \\
118 \\
159 \\
201 \\
69 \\
80 \\
141 \\
104 \\
180 \\
54 \\
96 \\
41 \\
43\end{array}$ & $\begin{array}{r}362 \\
3 \\
1.230 \\
333 \\
51 \\
588 \\
391 \\
4 \\
403 \\
198 \\
172 \\
318 \\
92 \\
42 \\
357 \\
83 \\
63 \\
52 \\
121 \\
2 \\
149 \\
226 \\
90 \\
44 \\
2 \\
25 \\
20 \\
64 \\
85 \\
38 \\
40\end{array}$ & $\begin{array}{r}4,542 \\
1,512 \\
1,560 \\
389 \\
1,438 \\
380 \\
505 \\
1,125 \\
658 \\
171 \\
583 \\
223 \\
338 \\
149 \\
262 \\
98 \\
279 \\
92 \\
95 \\
148 \\
128 \\
192 \\
73 \\
99 \\
105 \\
91 \\
140 \\
49 \\
80 \\
37 \\
44\end{array}$ & $\begin{array}{r}1,644 \\
3,124 \\
1,324 \\
1,991 \\
655 \\
1,696 \\
1,375 \\
104 \\
371 \\
856 \\
249 \\
570 \\
318 \\
408 \\
260 \\
273 \\
64 \\
201 \\
103 \\
49 \\
65 \\
0 \\
115 \\
73 \\
51 \\
61 \\
11 \\
60 \\
7 \\
45 \\
0\end{array}$ & $\begin{array}{r}6.186 \\
4,636 \\
2,884 \\
2,380 \\
2,093 \\
2,076 \\
1.880 \\
1.229 \\
1.029 \\
1,027 \\
832 \\
793 \\
656 \\
557 \\
522 \\
371 \\
343 \\
293 \\
198 \\
197 \\
193 \\
192 \\
188 \\
172 \\
156 \\
152 \\
151 \\
109 \\
87 \\
82 \\
44\end{array}$ \\
\hline
\end{tabular}

* Content kapas > 50z

* Synthetic \& cellulusic, Staple \& Filament, excluded:

1. wool,other animal hair\& other vegetable.

2. tufted dan nonwoven.

DATA API: dar: berbagai sumber. 
jumlah $\pm 8,5$ juta mata pintal. Perincian peningkatan jumlah yanglebih besaradalah China dan Brazil, masing-masing dengan 18,7 juta dan' 3,7 juta dibandingkan Indo nesia dengan tambahan 32,5 juta selama 4 tahun. Menurut ITMF (International Textilemachinary Manufactures Federation) mata pintal Indonesia adalah 6,1 juta, sedangkan menurut catatan API jumlah mata pintal Indonesia dalam tahun 1991 adalah $\pm 6,2$ juta dan dalam tahun 1992 mencapai $\pm 6,8$ juta, perbedaan \pm 100.000 $\mathrm{mp}$ adalah disebabkan ITMF belum memperhitungkan impor mesin bekas.

Kapasitas pertenunan dunia selama 4 tahun ini bertambahdengan $\pm 20 \%$ menjadi \pm 4 juta atm (alat tenun mesin). Amerika Utara turun dengan \pm 30 ribu ATM menjadi \pm 336 ribu atm danEropa $B$ arat turun dengan \pm 31 ribu atm menjadi 267 ribu atm. Asia Timur (Japan, Korea, Hongkong, Taiwan dan Macao) turun dengan \pm 72 ribu atm. Dalam jangka waktu itu Indonesia menambah kapasitas pertenunannyadengan \pm 70 ribu atm menjadi \pm 181 ribu atm.

Peningkatan yang lebih besar dari Indonesia adalah China dan Rusia selama periode itu meningkatkan kapasitas pertenunannya dengan \pm 264 dan \pm 145 ribu atm, menjadi \pm 944 dan \pm 600 ribu atm. Tambahan lain yang berarti adalah Brazil dengan \pm 66 ribu menjadi \pm 265 ribu ATM Penurunan kapasitas negara maju ini memberi kesempatan bagi Indonesia untuk menjadi pemasok utama lembaran tekstil dunia.Perlu diperhatikan bahwa pada waktu yang sama Portugal meningkatkan pemintalannya dengan \pm 72.8 ribu $\mathrm{mp}$ menjadi \pm 1.7 juta $\mathrm{mp}$, serta menaikan pertenunannya dengan \pm 18 ribu menjadi \pm 44.5 ribu atm. Tidak aneh jika ME mengenakan call terhadap Indonesia pada akhirtahun 1992, untuk Kategori 1 (Cotton
Yam) dan Kat 35 (polyfilament fabrics) untuk melindungi salah satu negara anggotanya.

Untuk subsektor finishing, dyeing dan printing, Indonesia masih tertinggal jauh. Subsektor ini sangat padat modal, memerlukan tenaga skilled lebih banyak dibandingkan subsektor lainnya. Menjadi masalah,karena unitekonomi yang terkecil pada industri ini, biasanya lebih besar dari unit ekonomi yang terbesar untuk pertenunan. Di negara maju industri ini berdiri sendiri, sedangkan umumnya di Indonesia integrated dengan industri pertenunan.

Tidak tersedianya data untuk perajutan, baik didalam maupun diluar negeri, menyebabkan belum dapat dianalisa dengan tepat situasinya. Hal ini disebabkan v banyaknya industri rumah tangga yang memakai mesin rajut, mulai rajút tangan sampai mesin dengan teknologi yang terakhir, baik dinegara berkembang maupun dinegara maju. Jika dilihat angka kuota untuk pakaian rajut Indonesia, baik untuk Eropa maupun untuk AS, temyata kita juga mampu untuk turut bicara dipasar dunia pada tahun-tahun terakhir ini.

Mengingat besarnya persaingan untuk mendapatkan modal di pasar modal luarnegeri, maka akan sukarlah bagi negara berkembang lain untuk meningkatkan kapasitasnya secepat yang kita laksanakan pada tahun-tahun terakhir ini.

\section{Perkembangan Teknologi}

Penguasaan teknologi yang lebih maju adalah salah satu faktor yang akan menentukan hasil akhir dari perang dagang dinegaraketiga lokomotif penarik ekonomi dunia yang mencapai puncaknya pada saat ini.

Tịdak berlebihan jika dikatakan bahwa 
kekuatan utama ekonomi suatu bangsa terletak pada pemilikan teknologi, sebagaimana yang dibuktikan negara maju selama ini. Teknologi tersebut diperoleh dengan susah payah, mahal dan merupakan salah satu "assets" yang paling berharga miliknya. Pengalihan teknologi ini tidak -begitu saja dapat dilaksanakan dengan cuma-cumà, harganya akan harus dibayar si penerima dengan satu atau lain cara.

Walau perang dingin ideologi telah usai, tetapi masih banyak' kalau tidak dapat dikatakan bertambah banyak, negara diduniaini yangkeadaan ekonominya tidak bertambah baik dibandingkan dengan keadaan pada beberapa dasawarsa yang lalu.

Disatu pihak harus secepat mungkin mengejar ketinggalan, sedangkan pada sisi lain untuk waktu yang cukup lama, pasar dunia termasuk pasar dalam negeri, untuk hasil produksi pada tingkat teknologi yang kita kuasai, masih tersedia dengan luasnya.

Sehubungan ' dengan itu dikembangkanlah dua cara dalam pengembangan industri TPT, khususnya untuk perusahaan PMDN. Yang pertama dengan tujuan pemenuhan pasar dalam negeri serta pasar atau segmen pasar yang sama diluar negeri. Impor mesin bekas sekalipun, selama tidak terlalu usang teknologinya, dizinkan untuk memenuhi. keinginan pasar ini. Para pengusaha sendirilah yang harus memperhitungkan berapa lama tingkat kualitas produknya akan dapat bertahan, sehingga modalnya dapat kembali.

Yang kedua dengan sasaran pasar negara maju, dengan memilih teknologi untuk tingkat kualitas yang sesuai dengan kelompok konsumen yang dituju pada negara tersebut. Perlu dingat bahwa tidak seluruh konsumen disemua negara maju mempunyai tingkat permintaan yang tinggi. Terdapat juga kelompok berpenghasilan rendah,' antara lain para penganggur dan imigran; mahasiswa dạ generasi muda yang berpakaian seenaknya (walaupun after war baby-boomers telah mèncapai usia 40-an yang telah mapan). Itu di AS yang berbeda dengan PTE (Pasar Tunggal Eropa) dan Jepang. Perusahaan PMA hanya diizinkan mempergunakan mesin bekas; selama $85 \%$ produknya di-ekspor. Merekalah yang harus memperhitungkan sendiri teknologi yang sesuai untuk menembus pasar luar negeri, sésuai pengalamannya.

Harus dipahami bahwa meskipun profitperunit produksi untuk produk tujuan pasar segmen bawah adalah lebih rendah, tetapi profit marginnya selalu lebih tinggi dibandingkan produk menengah atas, karena saham "cost of capital" pada production costnya lebih kecil. Hal ini terutama disebabkan tingginya biaya modal.

Mengingat AS dan PTE menetapkan kuota untuk sebagian besar produk TPT, maka secara nasional, yang diharapkan adalah mencapai nilai tambah dan harga produk yang tertinggi yang mungkin diperoleh, sehinggapenghasilan devisanegaramenjádi besar. Para pengusaha berbeda pendapat mengenai ini, karena mengutamakan mencapai hasil terbesar untuk perusahaan dengan modal terbatas yang dimilikinya.

Lain halnya untuk segmen pasar atas yang masih dikuasai negara maju, karena pengaruh faktor merk, design dan fashion yang masih sangat dominan.

Penerapan teknologi păda industri TPT tidak dapat ditentukan secara pandangan makro, tetapi harus dianalisa sangat mendetail, bukan saja terhadap kategori, tetapi harus meliputi sub-kategori 
mengingat besamya variasi produk pada TPT.

Penelitian terhadap marketlah yang menentukan teknologi mana yang dipilih. Teknologi tinggi umumnya padat modal yang akan menyebabkan fixed-cost tinggi tetapi variabel cost rendah. Sedangkan teknologi yang lebih rendah menimbulkan fixed-cost yang lebih rendah dengan variabel-cost relatif tinggi.

Jika tersedia pasar yang relatif pasti, cukup besar dan fluktuasi penjualan kecil maka perusahaan akan memilih cara yang pertama. Dalam hal fluktuasi penjualan besar, kompetisi ketat, pasar yang berubah, baik karena musim, fashion maupun saingan, maka seyogyanya dipilih cara kedua.

Produk garmen untuk ekspor, sebagian besar termasuk kelompok ini, karena jumlah yang kecil dibawah skala ekonomi terkecil, karena terkena pembatasan kuota, apalagi dengan sistem pembagian kuota sementara kita yang tidak pasti.

Subsektor hulu TPT termasuk kelompok yang pertama, yang saham perangkat kerasnyamahal, sehingga tidakiah mungkin didirikan jika hanya mengandalkan modal dalam negeri saja karena biáya modal yang tinggi.

Dapat dikatakan hanya industri fiber yang hak patennya telah kadaluwarsa yang mampukitabangun. Tingginyabiaya royalti dan licensi bagi produk tertentu, menyebabkan industri TPT yang lebih hilir akan lebih mungkin bersaing jika membeli bahan baku atau setengah jadi tersểbut dari negara supplieryangmemiliki kemampuan kompetitif yang tinggi pada jenis tersebut. Padahal dikatakan oleh para ahli bahwa industri fiber dapat mengembangkan jenis , próduk dengan variasi tanpa batas.
Kendalanya adalah biaya Litbang yang sangat mahal, baik perangkat keras maupun perangkat lunaknya.

Pada tingkat tengah dari industri TPT, sebaǵian besar perusahaan memilih mesin dengan teknologi terbaru, diutamakan pada subproses dimana kemajuan teknologi untuk meningkatkan mutu dapat. dimanfaatkan sebesar mungkin.

Dinegara maju industri pakaian jadi yang berukuran kecil dan menengah berdiri sendiri dan tidak mengadakan vertical integration. Pengembangan dilaksanakan pada umumnya secara horizontal dengan penambahan jenis produk baru pada lokasi yang berbeda. Hanya perusahaan garment lama dan yang besar mengadakan seluruh kegiatan pembuatan garment pada satu lokasi. Yang meningkat dengan pesat pada saat ini adalah fashion houses yang membuat design sendiri, mencari atau menetapkan bahan dasamya serta mengatur penjualànnya; tetapi dengan subkontrak ke perusahaan lain untuk kegiatan selebihnya. Sering pula cutting dilaksanakannya, sendiri untuk memenuhi ketentuan rules of origin. Cara ini dilaksanakannya selain didalam negeri juga. OPT (Outward Processing Trade) di PTE atau super 807 di AS, kepada negara berkembang disekitarnya. Cara ini tidak ekonomis jika dilaksanakan kepada negara ASIA karena jaraknya yang jauh, kecuali produk yang ringan dan mahal.

Perusahaan garment yang besarpun sudah mengkombinasikan cara ini, sering dengan turnover yang lebih besar dibandingkan hasil produk sendiri.

Sebagian besar dari industri garment di negara maju adalah subcontrctors yang menerima bahan yang telah dipotong dan menyelesaikannya. Finishing dan packing tidak jarang diadakan oleh perusahaan lain yang khusus melaksanakannya. Ejekan para 
"pakar" (dalam tanda kutip), bahwa industri garment kita hanyalah "tukang jahit", janganlah terlalu diperhatikan. Setelah 30 tahun ternyata Jepang bersama ke-empat "little dragons-nya" sekalipun tidak dapat mengalahkan Italia yang memakai sistem tersebut, dan sampai tahun 1991 masih tetap-merupakan pemasok terbesar dunia. Design dan fashions yang ditetapkan oleh Fashion Houses Perancis dan Italia ini, telah menguasi segmen pasar atas yang sukar ditembus.

Sebelum designers kita diakui oleh konsumen dunia yang mungkin berarti beberapa puluh tahunlagi, makakonsentrasi pada saat ini adalah mempertahankan pasar menengah bawah kita dari rebutan pendatang baru, serta merebut produk pasar menengah atas dunia yang selama ini dikuasai negara Asia Timur, terlebih lagi karena negara-negara ini telah bersedia mengadakan relokasi industri pakaian jadinya, suatu cara yang sama sekali tidak dipikirkan negara industri lain.

\section{Perdagangan TPT}

Meskipun Longterm Agreement on Textiles, telah berakhir 20 tahun yang lalu, disusul Multi Fiber Arrangement (MFA) yang pertama pada tahun 1974 , ternyata negara maju tidak bersedia mengadakan restrukturiasi industrinya meninggalkan industri TPT, yang dijadikan sebenarnya alasan penyimpangandariketentuan GA'TT. Sekiranya Putaran Uruguay (PU) disetujui, dan perdagangan TPT setelah 10 tahun mendatang sepenuhnya berada di bawah naungan GATT, maka ini jika terjadi suatu pembatasan atas impor kategori tertentu di suatu negara, haruslah diberlakukan ketentuan global kuota. Maka dalam hal ini diperlukan foothold sebagai jaminan pintu masuk kedalam negara tersebut, karena pembatasan hanya dilaksanakan melalui para importir negera bersangkutan. Salah satu jalan keluarnya adalah dengan mengadakan saluran penjualan dinegara itu, antara lain melalui Trading Houses yang tidak kita miliki.

Baru pada tahun 1990 yang lalu ekspor tekstil dunia disamakan oleh ekspor pakaian jadi, masing-masing dengan 104 milyar US\$. World Trade Statistics pada International Trade Statistics 90-91 dari GATT memperlihatkan bahwa ekspor lembaran tekstil masih dikuasai negara maju, sedangkan sahamnya hanya berkurang sebesar $4 \%$, yaitu dari $66 \%$ menjadi $62 \%$ selama dasawarsa 80 -an. Penurunan saham negara maju ini hanyalah disebabkan turunnya ekspor Jepang, sedangkan ekspor TPT AS dan ME pada tahun 80-an itu tetap meningkat walaupun kecil. Karena itu adalah keliru bahwa industri tekstil hanyalah merupakanindustri yang padat karya dan hanya sesuai untuk negara berkembang saja (lihat tabel $2 \mathrm{~s} / \mathrm{d}$ 5).

Dari 15 negara pemasok lembaran tekstil terbesar dunia pada tahun 1990, 11 negara diantaranya negara industri, 8 dari ME (pada saat pasar tunggalnya belum dimulai), ditambah NIE dan China.

Eksportir lembaran tekstil terbeșar dunia masih tetap Jerman yang pada tahun 1990 bernilai US\$ 13.3 milyar, dengan export growth 1989-1990 untuk lembaran tekstilnya adalah $20 \%$, danmerupakan $3,5 \%$ dari ekpor manufactured goods negaranya. China, Hongkong, Taiwan dan Korea masing masing dengan saham $12,0,10,0$, 9,5 dan 9,5\% dari ekspormerchandise goods negaranya masing-masing, masih lebih besar dari saham tekstil pada ekspor Indo- 
nesia yang $8.5 \%$ dari manufactured Jepang, sedangkan kapasitas pemintalan goodsnya. Pada tahun 1990 itu 30\% tekstil dan pertenunan mereka terus menurun. dunia oleh 5 negara Asia Timur termasuk

Tabel 2

\begin{tabular}{|c|c|c|c|c|c|c|c|}
\hline Negara & $\begin{array}{l}\text { Nilai } 1990 \\
\text { milyar US\$ }\end{array}$ & $\begin{array}{l}\text { salua } \\
1980\end{array}$ & 1990 & $\begin{array}{l}\text { annu } \\
\text { grow } \\
1989\end{array}$ & $\begin{array}{l}\text { 1al } \\
1990\end{array}$ & $\begin{array}{c}\text { share } \\
\operatorname{manf} \\
1980\end{array}$ & $\begin{array}{l}\text { export } \\
\text { goods } \\
1990\end{array}$ \\
\hline $\begin{array}{l}\text { Hongkong * } \\
\text { Italy } \\
\text { China } \\
\text { S Korea } \\
\text { Germany } \\
\text { France } \\
\text { Taiwan } \\
\text { Portugal } \\
\text { Turkey } \\
\text { Thailand } \\
\text { UK } \\
\text { US } \\
\text { India } \\
\text { Netherlands } \\
\text { Belgium-Luxmb }\end{array}$ & $\begin{array}{r}15.4 \\
11.8 \\
9.7 \\
7.9 \\
7.0 \\
4.7 \\
4.2 \\
3.5 \\
3.3 \\
3.3 \\
3.0 \\
2.6 \\
2.5 \\
2.2 \\
2.0\end{array}$ & $\begin{array}{r}12.0 \\
11.0 \\
4.0 \\
7.0 \\
7.0 \\
5.5 \\
6.0 \\
1.5 \\
0.5 \\
0.5 \\
4.5 \\
3.0 \\
1.5 \\
2.0 \\
2.5\end{array}$ & $\begin{array}{r}13.5 \\
10.5 \\
8.5 \\
7.0 \\
6.0 \\
4.0 \\
3.5 \\
3.0 \\
3.0 \\
3.0 \\
2.5 \\
2.5 \\
2.0 \\
2.0 \\
2.0\end{array}$ & $\begin{array}{r}19.0 \\
4.0 \\
17.0 \\
5.0 \\
5.0 \\
10.0 \\
1.0 \\
13.0 \\
17.0 \\
45.0 \\
(6.0) \\
35.0 \\
24.0 \\
4.0 \\
6.0\end{array}$ & $\begin{array}{c}10.0 \\
25.0 \\
18.0 \\
(13.0) \\
25.0 \\
29.0 \\
(12.0) \\
35.0 \\
22.0 \\
15.0 \\
29.0 \\
16.0 \\
28.0 \\
39.0 \\
36.0\end{array}$ & $\begin{array}{r}25.0 \\
6.0 \\
9.0 \\
17.0 \\
1.5 \\
2.0 \\
12.5 \\
13.5 \\
4.5 \\
4.0 \\
1.5 \\
0.5 \\
7.0 \\
1.0 \\
1.5\end{array}$ & $\begin{array}{r}19.0 \\
7.0 \\
15.5 \\
12.0 \\
2.0 \\
2.0 \\
6.0 \\
21.5 \\
25.5 \\
14.5 \\
1.5 \\
0.5 \\
14.0 \\
1.5 \\
1.5\end{array}$ \\
\hline
\end{tabular}

* Re-export dari import Hongkong adalah 28.38

Sumber: GATT

Tabel 3

\begin{tabular}{|c|c|c|c|c|c|c|c|}
\hline \multicolumn{8}{|c|}{15 negara importir pakaian jadi terbesar dunia } \\
\hline Negara & $\begin{array}{l}\text { Nilai } 1990 \\
\text { milyar USS }\end{array}$ & $\begin{array}{r}\text { sa } \\
1980\end{array}$ & 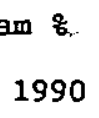 & $\begin{array}{l}\text { annu } \\
\text { grow } \\
1989\end{array}$ & th $_{1990}^{\text {al }}$ & $\begin{array}{l}\text { share } \\
\text { manf } \\
1980\end{array}$ & $\begin{array}{r}\text { export } \\
\text { goods } \\
1990\end{array}$ \\
\hline $\begin{array}{l}\text { US } \\
\text { Germany } \\
\text { Japan } \\
\text { France } \\
\text { UK } \\
\text { Hongkong } \\
\text { USSR } \\
\text { Netherlands } \\
\text { Belgia-Luxmb } \\
\text { Swiss } \\
\text { Italy } \\
\text { Sweden } \\
\text { Canada } \\
\text { Austria } \\
\text { Spain }\end{array}$ & $\begin{array}{r}27.0 \\
20.0 \\
8.7 \\
8.4 \\
7.0 \\
6.9 \\
4.8 \\
4.8 \\
3.6 \\
3.4 \\
2.6 \\
2.5 \\
2.4 \\
2.3 \\
1.6\end{array}$ & $\begin{array}{r}16.0 \\
19.5 \\
3.5 \\
6.0 \\
6.5 \\
1.5 \\
6.0 \\
6.5 \\
4.0 \\
3.5 \\
2.0 \\
3.0 \\
1.5 \\
2.0 \\
0.5\end{array}$ & $\begin{array}{r}22.5 \\
17.0 \\
7.5 \\
7.0 \\
6.0 \\
6.0 \\
4.5 \\
4.5 \\
3.0 \\
3.0 \\
2.0 \\
2.0 \\
2.0 \\
2.0 \\
1.5\end{array}$ & $\begin{array}{r}13.0 \\
1.0 \\
33.0 \\
6.0 \\
5.0 \\
39.0 \\
14.0 \\
(2.0) \\
1.0 \\
(1.0) \\
8.0 \\
(1.0) \\
14.0 \\
0.0 \\
50.0\end{array}$ & $\begin{array}{l}4.0 \\
37.0 \\
(3.0) \\
-31.0 \\
20.0 \\
21.0 \\
- \\
29.0 \\
23.0 \\
33.0 \\
27.0 \\
21.0 \\
10.0 \\
36.0 \\
59.0\end{array}$ & $\begin{array}{l}2.5 \\
4.5 \\
1.0 \\
2.0 \\
2.5 \\
3.0 \\
3.5 \\
3.5 \\
2.5 \\
4.0 \\
1.0 \\
4.0 \\
1.0 \\
4.0 \\
0.5\end{array}$ & $\begin{array}{l}5.0 \\
6.0 \\
3.5 \\
3.5 \\
3.0 \\
8.5 \\
4.0 \\
4.0 \\
.3 .0 \\
5.0 \\
1.5 \\
5.0 \\
2.0 \\
5.0 \\
2.0\end{array}$ \\
\hline
\end{tabular}

* Hongkong re-export $45.7 \%$ 
Tabel 4

\begin{tabular}{|c|c|c|c|c|c|c|c|}
\hline Negara & $\begin{array}{l}\text { Nilail990 } \\
\text { milyar US\$ }\end{array}$ & $\begin{array}{r}\text { sah } \\
: 1980\end{array}$ & $\begin{array}{l}1990 \\
1990\end{array}$ & $\begin{array}{c}\text { annu: } \\
\text { growt } \\
1989\end{array}$ & $\begin{array}{l}\text { al } \\
\text { th: } \\
1990\end{array}$ & $\begin{array}{r}\text { share } \\
\text { manf } \\
1980\end{array}$ & $\begin{array}{l}\text { export } \\
\text { goods: } \\
1990\end{array}$ \\
\hline $\begin{array}{l}\text { Germany } \\
\text { Italy } \\
\text { Hongkong } \star \\
\text { China } \\
\text { Belgia/Luxb } \\
\text { Taiwan } \\
\text { S Korea } \\
\text { France } \\
\text { Japan } \\
\text { US } \\
\text { UR } \\
\text { Netherlands } \\
\text { Swiss } \\
\text { Austria } \\
\text { Spain }\end{array}$ & $\begin{array}{r}13.3 \\
9.5 \\
8.2 \\
7.2 \\
6.4 \\
6.3 \\
6.2 \\
6.1 \\
5.9 \\
5.0 \\
4.4 \\
2.9 \\
2.6 \\
2.1 \\
1.5\end{array}$ & $\begin{array}{r}11.5 \\
7.5 \\
3.0 \\
4.5 \\
6.5 \\
3.0 \\
4.0 \\
6.0 \\
9.0 \\
6.5 \\
5.5 \\
4.0 \\
2.5 \\
2.0 \\
1.0\end{array}$ & $\begin{array}{r}12.0 \\
8.5 \\
7.5 \\
6.5 \\
5.5 \\
5.5 \\
5.5 \\
5.5 \\
5.5 \\
4.5 \\
4.0 \\
2.5 \\
2.5 \\
2.0 \\
1.5\end{array}$ & $\begin{array}{r}5.0 \\
6.0 \\
19.0 \\
3.0 \\
6.0 \\
20.0 \\
11.0 \\
7.0 \\
0.0 \\
12.0 \\
5.0 \\
(22.0) \\
(3.0) \\
5.0 \\
4.0 .\end{array}$ & $\begin{array}{r}20.0 \\
20.0 \\
8.0 \\
0.0 \\
20.0 \\
15.0 \\
15.0 \\
22.0 \\
6.0 \\
15.0 \\
22.0 \\
23.0 \\
21.0 \\
27.0 \\
30.0\end{array}$ & $\begin{array}{r}3.5 \\
5.5 \\
9.0 \\
14.0 \\
5.5 \\
9.0 \\
12.5 \\
3.0 \\
4.0 \\
1.5 \\
3.0 \\
3.0 \\
5.0 \\
6.0 \\
3.5\end{array}$ & $\begin{array}{r}3.5 \\
5.5 \\
10.0 \\
12.0 \\
5.5 \\
9.5 \\
9.5 \\
3.0 \\
2.0 \\
1.5 \\
2.5 \\
2.0 \\
4.0 \\
5.0 \\
2.5\end{array}$ \\
\hline
\end{tabular}

* Re-export dari import Hongkong adalah $10.8 \%$

Tabel 5

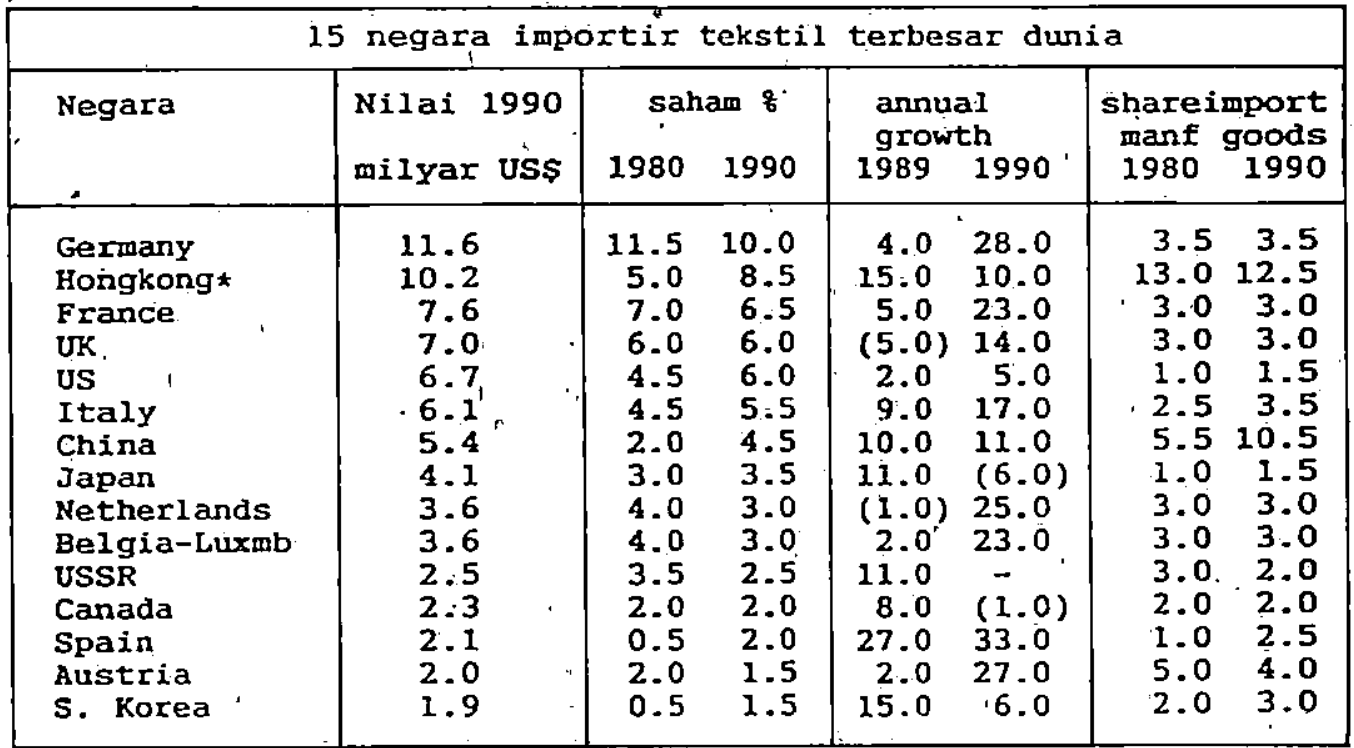

* Hongkong re-export 10.88 tanpa di-proses. 
Dalam hal pakaian jadi, pemașok terbesamya yaitu sebesar $53 \%$ adalah negara berkembang. Jika tidak diperhitungkan reexport, maka Italia tetap bertahan sebagai pemasok terbesar dunia dengan nilai 11.8 milyarUS \$ pada tahun 1990, dengan growth terhadap tahun sebelumnya sebesar $25 \%$, dan merupakan $7 \%$ dan export manufactured goodsnya.

Walaupun peningkatan ekspor pakaian jadi dunia terbesär berasal' dari negara berkembang dan merupakan peningkatan perdagangan manufactured goods tercepat didunia, tetapi sebagian besar disebabkan perubahan nilai dollar dan peningkatan karena inflasi yang tinggi dinegara berkembang. Hasil ekspor pakaian jadi dari negara berkembang ini, sebagian besar untukmembiayai perangkat keras danlunak ditambah ekspor bahan baku dan setengah jadi dari negara maju, atau melalui OPT di ME dan extra 807 dari AS. Dari tabel 13 terlihat pada tahun 1990, 8 dari 15 pémasok pakaian jadi terbesar adalah dari negara industri, dan 8 diantaranya adalah anggota ME, pada saat belum berlakunya pasar tunggal sebagai kelanjutan pasar bersamanya.

Resesi ekonomi duniásebagai sebab atau mungkin juga sebagai akibat perang dagang ekonomi yang berkepanjangan, tidak dapat diatasi ketiga adikuasa ekonomi dunia, walaupun mereka tetap merupakan pengimpor TPT terbesar dengan urutan impor PTE, AS dan Jepang. Karena itu perlulah ditinjau keadaan negara-negara ini secara lebih mendalam.

Pasar Tunggal Eropa

Produksi TPT Eropa menurun hampir diseluruh negara anggotanya berawal pada pertengahan tahun 1991, dan masih berjalan terus. Penurunan yang lebih tajam terjadi pada saat kemelut moneter pertengahan tahun 1992. Hanya industri non-woven yang berkembang terus, meningkat sejak awal tahun 70-an dengan pertumbuhan sekitar 6-10\% per tahunnya. PTE telah memperpanjang perjanjian bilateral dibawah naungan MFA dengan semua mitra dagangnya, sebagian besar selama setahun, sedangkan dengan Indonesia selama 2 tahun dengan kemungkinan perpanjangan 1 tahun lagi, tergantung perkembangan $\mathrm{PU}$ dan disetujui kedua pihak.Sebagai imbalan Indonesiamendapat uplift pada komoditi yang terkena kuota dengan jumlah yang cukup berarti. Mengingat bentuk dasar MFA masih tetap berlaku, maka ekspor TPT ke PTE hendaknya tidak dengan peningkatan yang mendadak, khususnya pada kätegori yang akan menyebabkan konfrontasi dengan industri mereka, sehingga tidaklah gampang untuk dikenakan call yang akan menjadi restraint limit. Sebelum berlakunya PTE, kita dapat melakukan surge pada kategori yang performancenya telah jauh diatas basket exit trshold, sehingga dapatmencapai angka kuota yang tinggi, tanpa terkena hukuman yang berarti. Hal ini dapat kita lakukan karena terlambatnya monitoring import Indonesia dan total ExtraEC import ? oleh negara anggotanya. Kegesitan para pengusaha telah dapat memanfaatkan tenggang, waktu terlambatnya laporan 3 bulan tersebut, sehingga selalu angka kuota yang dicapai jauhlebih besar dari pemegang kuota PTE sebelumnya. 
Tabel 6

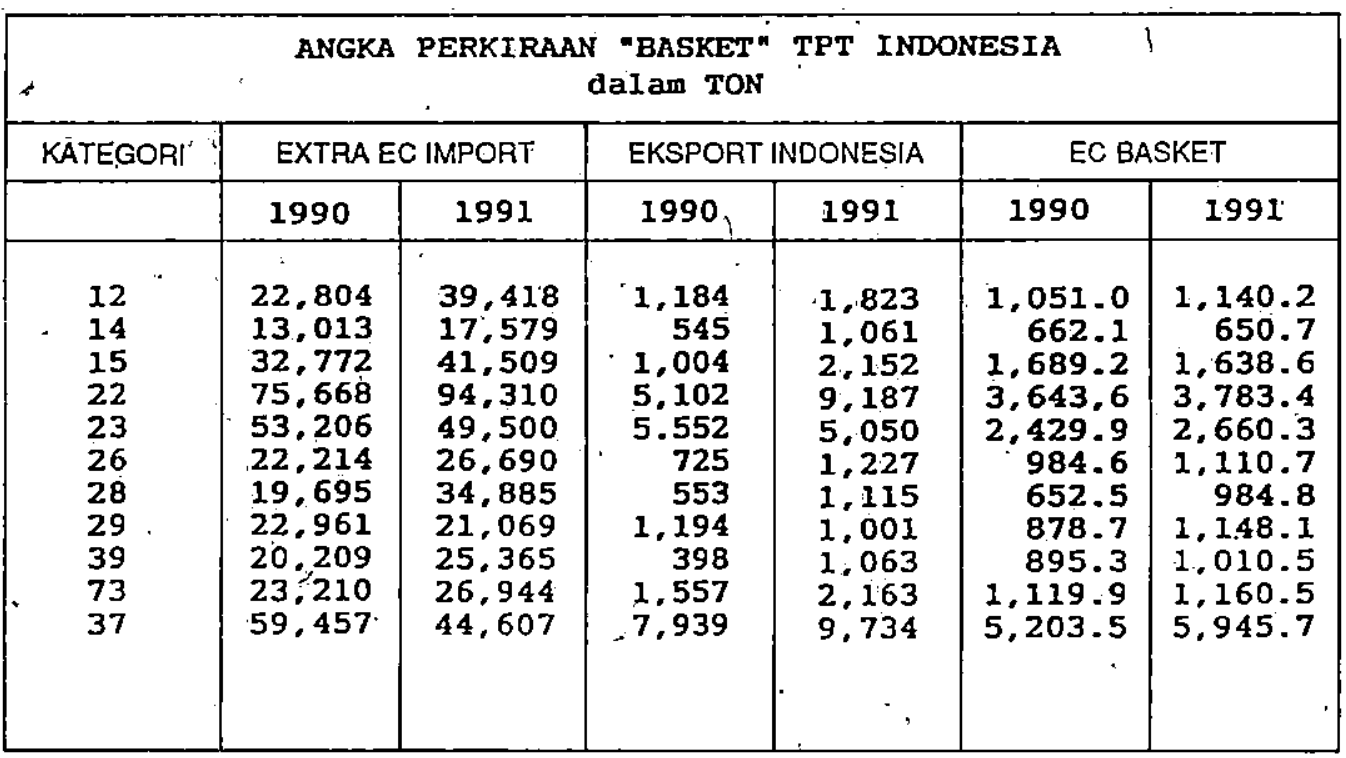

Indonesia dalam tahun 1980 olch ME untuk pertama kali terkena pembatasan, dengan kuota yang diperoleh pada posisi urutan pemegang kuota ke-4 sampai ke-6, tetapi pada saat ini biasanya kita mendapatkan kuota yang terbesar dibandingkan pemegang kuota sebelumnya.

Kemclut moneter ME pada semester keduatahun 1992, memberikan kesempatan bagi pengusaha Indonesia untuk memasuki pasarEropa, memperkenalkan produk hasil investasi yang diadakan pada awal tahun 90-an yang lalu, praktis dengan harga perkenalan. Pada saat itu penanaman mo'dal pada industri TPT kita scbagian besar masih pada tahap penyicilan bunga saja dan masih memperoleh grace period penyicilan hutang pokoknya. Faktor ketidakpastian yang dihadapis šebagiàn besar negara anggota ME pada waktu itu, memaksa para importirnya untuk tidak memesan produk TPT dalam jumlah besar dan untuk jangka waktu yang panjang. Keadaan ini membüka kesempatan bagi pengusaha Indonesia, sehingga ekspor TPT Indonesia ke ME meningkat dengan tajam, pada saat extra-EC import menurun. Ini berarti tidak terdapat market disruption, suatu syarat untuk dapat dikenakan call for consultation. Walaupun begitu Indonesia dikenakan call untuk 3 kategori, sehingga untuk kategori yang pertama diantara yang terkena call, diusulkan oleh pihak pengusaha untuk dibawa masalahnya ke TSB, karena call pada saat tidak terdapat market diruption. Pada akhir tahun 1992 itu, untuk kat 35 (poly filament fabrics) kita memperoleh kuota sebesar 13;200 ton, sedangkan pemegang kuota terbesar sebelumnya adalah Taiwan dengan 5.888 ton. Untuk kat 21 (anoraks, windcheaters) kita mencapai kuota 25.4 juta potong terhadap Hongkong pemegang kuota terbesar sebclumnya dèngan 16.8 juta 
potong, sedangkan untuk kat 1 (cotton yams) kita mencapai kuọta tertinggi diantara negara net importer kapas yang telah terkena pembatasan.

Diterimanya konsultasi dan penetapan kuota tersebut dengan perhitungan jangka panjang, antisipasi keadaan ekonomi ME, sehingga dapat saja terkena call dibelakang hari pada saat kemungkinan perfonnance kita malahan lebih rendah tetapi beralasan karena memang mengganggu pasar. Keberanian meningkatkan ekśpor dengan sangat cepat (surge) untuk kategori yang jelas telah melampaui basket exit treshold, walaupun dengan perhitungan, tidaklah dapat diterapkan lagi setelah berlakunya PTE, karena monitoring importnya sudah lebih cepat. Kategori yang telah mendekati basket exit treshold akan diikuti dengan extrat ketat. Jadi untuk selanjutnya kita harus berusaha agarpeningkatannya lebih landai. Kalau para pengusaha tidak dapatmenahan diri,makaterpaksa dipikirkankemungkinan mengadakan suatu mekanisme yang tidak diinginkan.

Lain halnya jika PU telah tercapai, yang diharapkan akan berhasil sebelum April 1994, karena telah disetujuinya perpanjangan prosedur fasttrack untuk PU oleh Conggress AS. Sebagaimana diketahui macetnya PU selama ini adalah karena pertentangan kelompok CAIRNS (baca: AS) dengan ME (baca: Perancis) mengenai proteksi dan subsidi produk pertanian. Dengan adanya persetujuan PU maka kita akanlebih bebas mempercepatpeningkatan ekspor, karena penetapan restraint limit tidak lagi secara bilateral, tetapi secara multilateral melalui TMB (Textile Monitoring Body) yang akan dibentuk oleh Textile Committe GATT.

- Dalam tahun 1988, ekspor Indonesia masih
345 juta ECU.(1 European Currency Unit = 1.2 US\$), dan meningkat menjadi 685 juta ECU hanya selama setengah tahun 1992. yang selama periode itu naik dari peringkat pemasok ke-17 menjadi ke-7. Saingän pemasok dengan peningkatan yang besar. adalah negara yang mendapat preferensi khusus dari ME, yaitu negara sekitar Lautan Tengah disusul negara produsen kapas. Pada saat ini negara bekas Block Timur juga mendapat perlakuan khusus, sebagai pemenuhan janji karena kesediannya untuk meninggalkan sistem komunis.

Seharusnya pada, tahun ini Masyarakat Eropa mengadakan pesta akbar, merayakan tercapainya PTE, yang menjadikan mereka memiliki satu single market yang terbesar didunia melampaui AS dan Jepang.

Ternyata ditiap 12 negara anggotanya timbul rasa ketidakpastian karena pertumbuhan ekonomi yang terhenti, dengan angkaunemployment rate $13 \%$ yang tertinggi' selama 30 tahun.' Diperkirakan pada tahap pertama berlakunya PTE, akan tercapai manfaat pada konsumen', karena turunnya harga dan meningkatnya pilihan atas jenis dan kwalitas produk. Pada tahap pertama itu, kemungkinan produsen akan berkuranguntungnya, dengankemungkinan merugi, terlebih bagi yang selama ini memegang monopoli dan mendapat proteksi di negaranya. Dalam jangka panjang setelah dunia usaha menyesuaikan diri, yaitu penyesuaian skala produksi, learning gurve effect, hapusnya ineffisiency, terjadinya mergerdan akuisisi melampaui tapal batas, dsb, akan meningkatlah economic welfare dari masyarakat "Eropa. Turunnya harga mencapai tingkat baru, walaupun tidak langsung mengenai jenis produk kita yang berbeda, tetapi untuk mempertāhankan 
kelompok konsumen, sehingga tidak pindah ke produk intra EC, maka pada tingkat harga yang ingin dipertahankan, haruslah ditingkatkán mutu dan variasi.

\section{Amerika Serikat}

Penjualan TPT di AS pada waktu Natal tahun 1992 telah meningkat cukup tinggi dibandingkan waktu yang sama tahun. - 1991, yang memberikan harapan cerah yang ditunggu semua orang, temyata pada tengah tahun 1992 sebagian besar pelaku sektor penjualan melaporkan bahwa penjualan mereka pada semester pertama tahun ini kembali menurun, lebih rendah bukan saja dari semester sebelumnya, tetapi juga terhadap waktu yang sama tahun lalu. Untuk kwartal I 1993 diperoleh angka growth 0,9\% dibandingkan $4.7 \%$ pada triwulan akhir untuk adjusted annual rate (angka $4 x$ angka pertumbuhan per tahun). Padahal untuk pertama kalinya pada tahun 1991 total nilai impor pakaian jadi menurun, walaupun volume impor naik.

Ekspor TPT Indonesia tahun lalu meningkat cukup tinggi, yaitu sebesar $33 \%$, namun masíh dibawah beberapa negara lain, diantaranya Thailand, Bangladesh dan Brazil. Pada tahun 1991 perkembangan ekspor TPT'ke AS lcbih mengecewakan, karcna negatif. Keadaan ini' disebabkan banyaknya potongan carry forward pada tahun 1990 untuk membebaskan produk yang terkena embargo. Pertumbuhan tahun 1992 karena adanya uplift yang diperoleh pada saat perpanjangan agreement. Pada tahun 1992 ekspor TPT Indonesia ke AS sebesar 0.99 milyar US\$ tidak lagi yang terbesar, telah dikalahkan oleh Singapura dengan perbedaan yang sangat besar yaitu. 1.3 milyar US\$.
Perubahan prinsip, terjadi dalam policy, perdagangan AS pada Clinton Administration', dibandingkan masa Presiden Bush, dari fair trade (pengganti free trade) menjadi managed trade. Bentuk bagaimana perubahan ini sebenamya masih ditunggu oleh semua pihak, terutama terhadap Japan yaitu negara dengan surplus perdagangan terbesar, sedangkan AS negara yang balans negatif terbesar didunia. Dampaknya akan terkena juga ke negara lain.

Melihat pada call atas beberapa kategori terhadap Indonesia yang terakhir disampaikan yaitu woolen suit dan woolen trousers, dibandingkan impor dari negara lain, temyata adanya perlakuan khusus yang diberikan oleh AS kepada Caribia dan Amerika Latin yang tidak dikenakan call walaupun ekspor yang lebih besar. Disamping itu pesanan melalui sistem 807 (outward processing trade) terus meningkat yang akan menguntungkan negara dekat disekitar AS.

Penerapan sistem quick response di negaranya, 'memungkinkan buyer 'AS memaksakah para eksportir untuk mempersingkat leadtime, dan dampak negatif yang terbesarkarena cara ini adalah bagi Indonesia yang letaknya terjauh dari AS. Kelemahan deliverytime ini harus dapat diatasi dengan percepatan dalam proses produksi. Hanyalah kemungkinan AS̀ menjadi maju yang pertama yang mengatasi resesi, yang akan mendorong pengusaha Indonesia untuk tetap memprioritaskan AS sebagai negara tujuan ekspornya saat ini.

Sementara itù masa depan NAFTA masing terkatung-katúng. Selama tidak diadakan perjanjian tambahan khusus dengan Meksiko, mengenai proteksi 
lingkungan, masalah HAM dan intelectual propenty right, diragukan agreement ini akan disampaikan Clinton ke Congress sebelum batas waktu akhir tahun ini. Canada House of Commons dan Canadian Senate telah menyetujui implementasi NAFTA, dengan sarat baru berlaku jika AS dan Mexico telah meratifikasi perjanjian tersebut. Clinton Administration belum meneruskan draft NAFTA yang telah disetujui oleh Adm̈inistrasi Bush, karena menginginkan side agreement terlebih dahulu mengenai masalah diatas: Canada dan Mexico menolak usul AS mengenai ini, untuk menggunakań trade sanction jika ada pelanggaran, karena bertentangan dengan ketentuan GATT, yang tidak menyetujui trade sanction karena masalah yang bukan masalah trade. Tanggal 27 Aprili993 Congress tclah menyetujui perpanjangan prosedure "fast track" sampai April 1994 untuk perjanjian Putaran Uruguaay, dengan ketentuan bahwa persetujuan tersebut sudah disampaikan selaimbat-lambatnya tanggal 15 Desember 1993. Prosedure fast track adalah ketentuan bahwa pilihan dari Congress hanyalah menolah atau menyetujui sepenuhnya isi suatu perjanjian yang dimintakan ratifikasinya, dalam waktu 90 hari, tanpa diperkenankan mengadakan perubahan.

\section{Jepang}

Menurunnya consumer spending sepanjang tahun 1992 menyebabkan terjadi penurunan supply yang besar; dengan korban pertamanya produksi dalam negeri.
Departement store sales untuk apparel turun menjadi $97.4 \%$ sama dengan 33.6 milyar yen. Menguatnya mata uang yen, terutama terhadap US\$. menambah pula lemahnya - daya saing industri ini terhadap saingan luar negerinya, bukan saja di dalam negeri tetapi juga produk ekspor ke ekspor ke negara yang terkait dengan US\$. Hanya bahan baku dan setengah jadi dari acrylic yạng meningkat besar yaitu $13 \%$ menjadi $>200$ ribu ton, walaupun harganya sedikit menurun. Urutan negara tujuan ekspor ini adalah China sebesar 61, Taiwan 21.5, Indonesia 20.,5 dan Korsel 19.7 ribu ton.

Disemua negara maju industri untuk tufted carpet meningkat, walaupun keadaan ekonomi yang tidak begitu menggembirakan, tetapi próduksi Jepang menunun dari 92.5 ton pada tahun 1991 menjadi 84 ribu ton untuk tahun 1992. Kecuali produk khusus tekstil, a.l. spandex dan mmf tertentu, seluruh kegiatan industri tekstilnya menurun dengan drastị. Sejak tahun 1986 Jepang merupakan negara pengimpor TPT terbesar ketiga dunia setelah AS dan Germany. Urutan Supplier TPT ke Jepang adalah China, Korea, Italy, disusul dengan jumlah yang jauh lebih kecil tetapi hampir sama besar adalah ȦS, Taiwan, Thailand, Hongkong, Indonesia, France, India dan UK. Untuk pertama kali dalam tahun 1992 Indonesia termasuk yang dicatat dan tidak lagi termásuk kelompok sisa negara lain. Indonesia tercatat sebagai supplier Cotton fabrics terbesar kedua dengan 38:2 juta sme, tetapi berbeda jauh dengan pemasok utama China dengan 532 juta sme. Total.impor adalah $668.7 \mathrm{sme}$. 
Tabel 7

\begin{tabular}{|l|r|r|r|r|r|}
\hline \multicolumn{7}{|c|}{-IMPOR TPT DARI 10 PEMASOK UTAMA JAPAN } \\
Dalar juta USS \\
\hline & 1992 & $92 / 91$ & 1991 & $91 / 90$ & 1990 \\
\hline DUNIA & 14.284 & 113.7 & 12.563 & 109.5 & 11,475 \\
CHINA & 5.739 & 139.9 & 4.103 & 132.6 & 3.094 \\
KOREA & 2.317 & 93.3 & 2.483 & 101.8 & 2.493 \\
ITALY & 1.351 & 89.9 & 1.502 & 89.0 & 1.688 \\
USA & 800 & 112.0 & 714 & 124.0 & 576 \\
TAIWAN & 685 & 93.1 & 736 & 105.0 & 701 \\
THAILAND & 417 & 129.5 & 322 & 119.7 & 269 \\
PAKISTAN & 381 & 81.4 & 468 & 117.9 & 397 \\
INDONESIA & 368 & 171.9 & $\star 214$ & $\star 143.6$ & $\star 149$ \\
HONGKONG & 326 & 106.2 & 307 & 95.0 & 323 \\
FRANCE & 298 & 108.8 & 274 & 83.8 & 327 \\
UK & NA & NA & 293 & 81.2 & 361 \\
\hline
\end{tabular}

* angka BPS

Sumber: The Japanese Federation Importers Organisations.

ISP (Index Spesialisasi Perdagangan) TPT 1991 Indonesia dengan Japan adalah 0.2476 dengan trade balance US $\$ 84.7$ juta untuk Indonesia, yang lebih besardari tahun 1990 dengan ISP 0.1466 dengan trade balance untuk Indonesia scbesar US $\$ 37.5$ juta. ISP adalah rasio balance of trade terhadap total trade, berkisardari 1 atau impornihil sampai (1) yaitu ekspor nihil.

\section{Negara-negara Pesaing}

Sudah waktunya bagi kita secara agresif untuk memasok tekstil ke negaranegara ini, yang jika tidak didukung dengan sarana moneter hanya akan dimanfaatkan olehnegará perantara saja seperti Singapore, Timur Tengah dan Hongkong. Malahan pada saat ini ME melaksanakan transhipment produk kita ke Afrika dan Eropa Timur.

\section{China}

Walaupun terdapat peningkatan yang tinggi dalam jumlah mata pintal di China selama 5 tahun 1986-1991, tetapi dalam Rencana 5 tahun 1991-1995 jumlah mata pintal tidak akan bertambah karena 10 juta mata pintal baru hanya untuk mengganti, diantaranya 3 juta mata pintal tahun 1949 yang di-scrap, tctapi produksi dengan mesin baru ini akan meningkat. Pengaruh terbesar akan terasa oleh Hongkongyang pada tahun 1991 memasok USS\$ 1 milyar hasil reekspomya. Ekspor TPT dari China pada tahun 1990 yang besamya $8.4 \%$ dari trade dunia dengan jumlah US\$16.9 milyar ditargetkan menjadi US\$20 milyar pada tahun 1995. Tetapi temyata pada tahun 1992 saja target ini telah dilampaui dengan jumlah yang jauh lebih besar yaitu US\$ 24 milyar, dengan growth untuk tekstil $43 \%$ dan pakaian jadi $73 \%$. Laporan Chinese 
Ministry of Textiles ini ditambahkan dengan pernyataan bahwa impor juga meningkat tanpa memberikan data pendukungnya.

Diperkirakan kendala terbesar yang akan dihadapi China adalah peningkatan ekonominya yang demikian besar dan akan menyerap sebagian besar produk pertumbuhanindustriTPT-nya.Policy yang diterapkan kelihatannya dengan membuka keran impor untuk kebutuhan dalam negerinya, sempentara itu peningkatan ekspor dengan pemanfaatan penanaman modal.

Terbentuknya blok' ekonomi dunia yang dirasakan sebagai langkah awal proteksi yang ditujukan kepada mereka, diantisipasi negera NIE, terutama Taiwan dan Hongkong dengan mengadakan investasi di China.

Setelah pemulihan hubungan diplómatik dengan KORSEL, maka dalam tahun 1992 stock yang bertumpuk sebelumnya di Korsel dilepaskannya ke China, terutama stock filament fabric dan yam. Kelihatannya kelebihan stock ini tidak dapat seluruhnya ditampung oleh China, sehingga negara-negara lain juga menjadi sasaran. Peningkatan produksi syntetic filament China terlambat dibandingkan dengan peningkatan sub-sektor TPT lainnya baik kwalitas maupun kwantitasnya. Walaupun dalam dasawarsa 80-an China sudah melewati AS sebagai produsen kapas terbesardunia, namun peningkatan ini lebih kecil dari peningkatan produksi TPT dalam negerinya, sedangkan musim tanam tahun ini diperkirakan tidak sebaik tahun sebelumnya. Direncanakan dalam 5 tahun mendatang peningkatan ekspor TPT China terutama ke Eropa Timur yang selama ini karena masalah politik belum dijamahnya.

Dalam tahun 1991 ISP TPT (termasuk serat tekstil) antara Indonesia dengan China adalah (0.8435) dengan trade balance untuk China sebesar US\$ 81.67 juta. Posisi ini lebih baik dari tahun 1990 yang (0.9704) dengan balance of trade sebesar US\$ 87.2 juta untuk China. Tanpa serat tekstil ISP. TPT tahun 1991 adalah (0.7505) dengan balance tradescbesar US\$ 31.97 untuk China, sedangkan pada tahun sebelumnya keadaan jauhlebih buruk, yaitu (0.9999) walaupun balance of trade hanya US\$ 20.26 juta. Keadaan ini tidak mencerminkankeadaan sebenamya,karena tanpa memperhitungkan transshipment melalui Hongkong. Jika China dapat mengatasi kebutuhan yang melonjak didalam negerinya dan tetap mendapat pelayanan MFN dari AS, negara dengan kemampuan teknologi sedikit diatas kita dan dengan biaya upah yang hampir sama, akan sukar kita tandingi, seandainya kita hanya terpaku pada kondisi sarana pendukung seperti yang tersedia selama ini. Yang merisaukan adalah neraca negatif TPT ini, yang terbesaradalah saham pakaian jadi, sesudah serat kapas.

\section{Taiwan}

Dalam tahun 1991 ekspor TPT-nya melintasi selat. Taiwan ke China via Hongkong menjadi US\$2.1 milyar, tetapi setelah dimulainya perdagangan langsung antara Taiwan dan China ternyata pertumbuhannya tidak lagi demikian cepat, hanya menjadi US\$ 1.56 milyar sampai Agustus 1992. Trade dari China ke Taiwan malahan menurun dibandingkan dengan sebelumnya. Hal ini terutama karena ditinggalkannya peran Hongkong yang mempunyai keahlian khusus dalam perdagangan.

Trayek penerbangan langsung antara Taipei dengan Ho Chin Minh City pada bulan September 1992 akan memperlancar 
pengembangan trade TPT nya ke negara yang mempunyai kebudayaan yang sama. Dalam menghadapi abad "ASIA" mendatang pemerintah Taiwan merencanakan akan menjadikan seluruh pulau Taiwan sebagai zona perdagangan bebas dan mengubah Taiwan sebagai pusat usaha intemasional untuk industri-industri multi-nasional. ISPTPT Indonesia terhadap Taiwan adalah (0.8465) dengan balance of trade US\$ 177.83 juta untuk Taiwan, yang sebagian besar untuk tekstil, yang turut mendorong ekspor pakaian jadi kita. Ini disebabkan tidak terdapatnya produk tertentu disini, serta pemanfaatan usance L/C yang menarik. ISP 1990 adalah lebih besar (0.9274) dengantrade balance sebesar US\$214.54 juta untuk Taiwan.

\section{Hongkong}

Sejak semula sampai sekarang TPT menupakan penghasil devisa terbesamya. Dalam tahun 1990 ekspor TPT seluruhnya US\$23.6 milyar dan impomya US\$17.1 milyar. Hongkong merupakan pemasok terbesar kedua untuk pakaian jadi setelah Italy dan terbesar ketiga setelah Germany dan Italy untuk tekstil. Dengan terus meningkatnya teknologi dan permesinannya Hongkong berusaha untuk berada digaris depan dalam pengadaan jenis produk tekstil baru untuk industri pakaian jadi. ISP TPT 1991 adalah 0.4358 dengan trade balance US $\$ 87.3$ juta untuk Indonesia, yang lebih besar dari tahun 1990 dengan ISP 0.1574 dan balance of trade sebesar US $\$ 24.92$ juta, sebagian besar transshipment ke China. Kalau transshipment ke China ini diperhitungkan maka trade balanceIndonesia dengan China adalah positif untuk Indonesia dan negartif terhadap Hongkong yang terutama discbabkan fac- tor L/C yang dimanfaatkan perusahaan garment Indonesia.

\section{Korea Selatan}

Dalam tahun 1991 ekspor TPT Korsel (termasuk serat tekstil) adalah US\$ 15.47 milyar, yang terdiri dari US\$ 8.43 untuk produk tekstil, 5.7 unituk tekstil dan 1.34 milyar untuk serat tekstil. Impor TPT adalah US $\$ 4.05$ milyar, menunjukkan surplus perdagangan TPT negara NIE ini, lebih dari US\$10 milyar. Saham TPT Korea ke AS, Jepang dan ME menurun drastis dalam tahun 1991. Keadaan ini memaksa sebagian besar industri TPT KORSEL mengalihkan pabriknya ke negara lain. ISP TPT Indonesia tahun 1991 (0.7391) dengan trade balance US\$ 258.9 juta, sebagian besar dalam bentuk tekstil wool yang diperlukan oleh industri pakaian jadi kita sebagai bahan baku, karena tidak tersedia didalam negeri. ISP ini lebih baik dibandingkan tahun 1990 yang (0.8404) dan berjumlah US\$ 155.6 juta.

Asean

Perdagangan TPT antara Indonesia dengan ASEAN lainnya, selama dasawarsa 80-an adalah positif untuk Indonesia, kecuali negatif untuk tekstil pada tahun 1981 dan 1982. Untuk serat tekstil selamanya negatif. Angka perdagangan antar ASEAN tidak memperlihatkan keadaan yang sebenamya karena re-export Singapore ke Indonesia sebagian besar berasal dari luar ASEAN dan re-export Singapore dari Indonesia hanya sebagian kecil ke wilayah ASEAN. Dalam tahun 1992 ekspor TPT Indonesia ke ASEAN adalah USS $\$ 1435.4$ juta naik dari USS\$ 822.8 juta pada tahun 1991 (US\$ $\$ 1272.2$ 
juta naik dari US\$ 725.7 juta juta diantaranya ke Singapore). ISP TPT Indonesia dengan ASEAN pada tahun 1991, adalah cukup besar yaitu 0.941 , tetapi jika Singapore tidak diperhitungkan angka ISP turun menjadi 0.791. ASEAN swap untuk Eropa ternyata belum berhasil. Pendekatan antara Singapore dan Indonesia, masih tersangkut mengenai Certificate of Origin (CO). Dalam kenyataan dilapangan; malahan oleh suatu negara dipalsukan $\mathrm{CO}-$ nya negara lain agar dapat mengekspor maka tidak ada ruginya memenuhi permintaan Singapore ini.

\section{Penutup}

Demikianlah beberapa aspektentang perkembangan industri pertekstilan ditengah-tengah perkembangan industri tekstil dunia. Pemaparan ini diharapkan dapat memberikan gambaran mengenai posisi dan tantangan industri tekstil kita di pasar intemasional. 